\title{
Umberto Eco's The Name of the Rose and Intertextuality: Eastern Themes
}

ManizheH AbDOLlahi abdolahm@sums.ac.ir

Shiraz University of Medical Sciences

\begin{abstract}
The Name of the Rose, first novel by Umberto Eco, the Italian novelist and semiotician was published in 1980. The story happens in the Middle Ages (14th century) in an abbey, having a large and wonderful library. This historical detective story is a complicated novel full of intricate signs and symbols. In this paper, some of the themes of The Name of the Rose found in Eastern texts are discussed that indicate intertextuality and the immense amount of knowledge that Eco had of literature. It is stated that the frame tale is very much similar to Kalila va Demna and some of the subplots of the novel have similarities with stories from ancient Iran and the Middle East.
\end{abstract}

Keywords: The Name of the Rose, Eastern literature, narrator, narration, frame tale. 


\section{Introduction}

Much has been written on The Name of the Rose, the first novel published by Umberto Eco, the Italian novelist and semiotician in 1980. One reason is the very intricate and complex plot of the story, which brings to mind other oral and written tales and stories in other cultures. The story happens in the Middle Ages (14th century) in an abbey, having a large and wonderful library. The protagonist of the novel is a Franciscan monk, William of Baskerville, accompanied by his novice disciple, Adso. William is commissioned to go to the Abbey in order to solve a dispute between the pope and the Franciscan monks. However, upon his arrival he is faced with a series of murders. Using his high intelligence and rational mind, William manages to unravel the mystery of the crimes. In the course of his enquiry, he discovers that the identity of the killer is closely dependent on discovering the secret of the library, which is supervised and directed by a blind librarian who hides the route to the library. The novel is called a historical novel (Theresa Coletti, 2009) and a detective story (Peter Bondanella, 2009); Capozzi lists a series of titles «metaphysical, mystery, detective or anti-detective story, post-modern, historiographic metafiction; historical, gothic or essay novel; bildungsroman» considering it difficult to label (1989: 412).

Being a semiotician, Eco uses many symbols and signs in this novel as well as many sentences in Latin making it more complicated for the readers; hence the need for The Key to the Name of the Rose (1999) to decipher such complexities of a novel that has been translated into twenty-two languages (Haft, White \& White, xii). According to the unlimited semiosis theory proposed by Eco, signs should be examined in the context of their social-cultural background. This paper attempts to explore and present certain underlying themes of the novel as well as some traces of Oriental thought, especially those found in ancient Iranian texts, comprising the basis of the narration observed in this novel.

\section{Pre-determination}

The novel begins with an intricate and mysterious introduction, as pointed out by the Italian translator who, during the holidays, finds the book but after performing some initial note-taking and translating the book, mysteriously loses the book because a friend of him who has taken the book has disappeared. Later, the translator goes through a series of mysterious events and unexpectedly finds the book in Buenos Aires, a faraway city, with a different title (using mirrors in chess). And this time, with no conscious determination on his part, he translates and publishes the book. «I don't know how comes I dared to decide to accomplish it» (1986: 7\&9). In many stories from the East, there is the same frame tale structure or story -within- the- story-technique, one of the most famous ones being, The Thousand and One Nights. Sabri Hafez (1989) discusses how the use of time in the Arabian Nights and The Name of the Rose are similar. More sophisticated examples are found in Nizami Ganjavi's works (especially the Haft Peykar) as well as in the book of Kalilah va Demna (Panchatantra), and of course 
Rumi's Mathnawi. In the novel under study, there are sequences of events that seem to be unrelated to each other, but at the end of the story it turns out that a subtle thread connects all events. Applying such illusions and indeterminate structures in the novel seems to stem from Oriental thinking as if human's fate is more predetermined than being the outcome of one's actions and activities in the world. Metaphorically speaking, when the predetermined role is played on the stage, the person is led to leave the scene. William, as a bright person with his experience-oriented mindset, first tries to get over the events by relying on his intelligence; if not successful, he tries to unravel the mystery and the sequence of events. However, exactly at the moment that he finds himself successful, he is suddenly confronted with the bitter fact that the final incident, i.e., the terrible library fire, could not have taken place without his own presence. He ponders «as if for centuries those ancient pages had been yearning for arson and were rejoicing in the sudden satisfaction of an immemorial thirst for ecpyrosis» (Eco 1986: 283). In other words, it seems that William with his high intellectual ability to solve the mystery was a means to execute and accomplish the inevitable destiny of the library. At the end of the book, with tears in his eyes looking at the terrifying sight of the fire, William bitterly discovers the truth. He states what Khayyam has also mentioned, «Tis all a Chequer-board of Nights and Days/Where Destiny with Men for Pieces plays:/ Hither and thither moves, and mates, and slays,/ And one by one back in the Closet lays» (Khayyam 2012: 109). Thus William attains enlightenment or illumination about the truth of man and his role or more accurately, his impotent and ineffective role in the course of events and concludes, «...the only truth lies in learning to free ourselves from insane passion for the truth» (Eco 1986: 287).

\section{The tale of Hakim Rouyan}

The core plot of The Name Of The Rose, encompassing all subplots religious and argumentative debates and other story-like texts as well as references to some historical events, is adapted from a story in One Thousand and One Nights named «Anecdote of Greek King and wise Rouyan», which is mentioned in the first volume of the fourth night's tale. In this tale, the king suffers from Vitiligo (leprosy), and as no doctor is able to cure his ailment, the news of the king's suffering reaches an old wise man named Rouyan. He treats the king and thus wins the respect of the king, becoming the king's trustee and special adviser. Other courtiers and the wazir, angered by his influence on the king, try to get the king against him, saying that he who treats such a cure with such speed and with a simple cure, can simply make anyone, especially the king sick at any time. The Shah (king) thus becomes suspicious of the physician and orders his assassination. In the last breath of life, and as the last wish of the king, Rouyan asks the king to personally read his last book. He took the book and, opening it, found that the pages were stuck together; so he put his finger to his mouth, wetted it with his spittle, and succeeded in opening the first leaf. He did the same with the second and the third, experiencing great difficulty each time. When six single sheets had been opened in this way, he tried to read but could find no manner of writing in the book. 'There is nothing written here,' 
he cried, and Hakim Rouyan answered: 'Go on turning.' The King went on turning the leaves but hardly had a minute passed when the venom (for the leaves of the book were indeed poisoned) began to work in the blood and body of the King. He fell back in terrible convulsions, crying 'Poisoned! Poisoned!' And Rouyan addressed him extemporising these lines: When the unjust judge/ Without justice judges, / Horrible, horrible things are done;/But more horrible things are done/ When justice judges / The unjust judge... (Mardrus 1964: 35-6)

The pages of the book were so stuck together that the reader inevitably licks his fingers to turn them. Poisoning the pages of the book is exactly the image adapted in the novel, The Name of the Rose showing the final fate of the monastery, and the hero. In fact, it appears that the main part of the story or original plot of this book is based on that found in One Thousand Nights and One Night. Rouyan's encouragement to the king and asking him to turn over more pages is a reminder of Jorge's anxiety and enthusiasm at the bottom of the book when strongly encourages William to read. In order to persuade him, he reads pages of the book by heart to make William, the seeker of knowledge, more curious to read the book. He also ironically promises Adso, who is the observer of the scene that his turn will come after William.

\section{Finding the lost horse}

In the opening pages of the book and before entering the monastery, a small story is mentioned in order to show the residents of the abbey the shrewd mind of William to and expand his reputation as a wise and intelligent ma. William identifies a runaway horse, the horse that the Grand Monk of the abbey loved most. This loss has caused much concern for the equerry. In addition to expressing the appearance of the horse from signs left on the road, William succeeds in discovering the whereabouts of the horse and informing the equerry. In answer to Adso's astonishment on how he knew the features of a horse that he has never seen, William runts his way of reflecting on the signs left around and decoding them afterward. This stuns Adso as well as those who are present. He has said that discovering the secret through reflection on the signs is as easy as finding human traces in the snow. The basis of this story is related to a story in ancient Oriental sources about the legendary genealogy of the Arab people. In this story, Nizar, the son of Adnan, the son of an Arab ancestor and one of the ancestors of the Prophet of Islam, was to choose one among his four children, called Mazer, Rabi'a, Ayyar and Anmar (actually of four ancient fictional Arab tribes), as his successor. He could hardly make such a difficult decision, so he asked an Arab scholar to help him in this regard. The sons had to prove their intelligence in order to succeed their father. Similarly they had to solve the mystery of finding a lost camel. The earliest source of this story is the book Tarikh Al-Rosol va Al-Muluk (of The History of Prophets and Kings), known as the Tabari's History written by Muhammad ibn Jarir Tabari (d. 310 AH / 921 AD). Later, the story is found in Murūj al-Dhahab wa-Ma'ādin al-Jawha, by Ali bin Hossein Ma'udi (d. 345 AH / 921 $\mathrm{AD})$. Since then, the same story with some changes is found in historical and fictional texts and 
even in popular literature, adjusting itself to suit the time, place, culture, and type of audience. According to Tabari, the boys saw the camel's footsteps, each referring to a sign of a camel in order to prove their intelligence. Anmar said the camel had one eye. Rabi'a said his tail was short. Ayyar said it had cross-eyes and Mazer said it was a fugitive and so the story went on. (Tabari 1989: 820-821) Interestingly, the boys' decoding of the camel riddle occurs exactly as William does in finding the horse, and they find out exactly the features of the camel from the signs left around. They accurately explain its traits. Another noteworthy point in the story of the horse in The Name of the Rose is that William describes to his novice disciple the features of an ideal horse. This description of an ideal horse can be found in Persian book, known as Qabusnameh, by Qaboos bin Voshmgir Ziari (d. 462 AH / 1083 AD)

\title{
5. The Story of a day-dreaming man
}

There is a story in the book about a man who had a little oil in his jar and was dreaming about selling the oil in order to be rich. Suddenly with his careless move, the jar fell to the ground and the oil was wasted and so gone was his dream. The same story appears in Kalilah and Demna (Panchatantra), as follows:

\begin{abstract}
They said that there was a pious man living next to a merchant of vegetable nectar and oil. Every morning, the merchant sent him some nectar and oil to increase his energy and maintain his health. The poor man would consume some and store some in a jar. The jar was being filled little by little. One day, he was looking at the jar and thinking: if I could sell this nectar and oil for ten drachmas, I could buy five sheep, and each month they give birth to five, then after a while, I would make money with the sheep, and marry a woman from a great family. Then, my wife would give birth to a son. I would name him a good name, teach him science and tactfulness, and if he refuses to be polite, I would punish him with this cane. He was so deeply involved in his dream that the cane suddenly struck the jar breaking it and the nectar and oil poured on him. (Monshi 1983: 263)
\end{abstract}

\section{Curing the disease of love}

In The Name of the Rose, in the section in which Adso falls in love with a rural girl, there are clear references to the study and analysis of love from the point of view of Muslim scholars, especially the views of Zakaria Razi (known as Rhazes) and Avicenna. Avicenna in his Canon of Medicine for the first time prescribes a healing method. It is worth mentioning that this method of treatment is based on his famous theory that views love and emotions as disease and accordingly prescribes a special treatment for love. After Avicenna, this method of treatment is found in other Persian and Arabic texts, both literary and medical, namely in the well-known books Chahar Maghale (The Four Articles) written by Nizami Aruzi and Sharafnameh (Eskandarnameh or Alexander namah) written 
by Nizami Gangavi, respectively. In the latter book, for instance, the protagonist, Archimedes, the Greek sage, falls in love with a Chinese servant. This method of treatment is found in all Iranian traditional medical texts, the most important one being Zakbireye Khwarazmshahi, a Persian medical encyclopedia. But perhaps the most famous version of the curing the disease of love is found in the first pages of Rumi's Mathnavi, in which the king's beloved slave-girl is sick because of falling in love with a goldsmith in Samarkand. As common in such tales, no doctor is able to diagnose the girl's illness and treat her. Following the king's prayers to the God, a pious sage comes to the court. Having observed the girl's complexion, the man speculates that the girl is involved in a secret love. Then, the sage, in order to verify this, takes the girl's pulse and utters the name of certain men he suspects the girl being in love with. Having vocalized the goldsmith's name, the sage noticed the rise of pulse beat and discovers the girl's secret, summoning the goldsmith to the palace. After meeting him, the girl becomes better. (Rumi 2004: 6)

It is clear that Umberto Eco is aware of these Eastern philosophical reflections on love, as well as the theories that attribute love to certain physical frailty, and consequently assign some medical methods for its treatment. In particular, in this part of the book, Adso explicitly mentions sources related to Avicenna's particular recommendations. Adso knows the methods Avicenna employs to diagnose the disease of love, one of which being to take the patient's pulse while trying to guess the lover's beloved by uttering the name of him/her. If the lover's pulse accelerates by hearing the name of the beloved, then the mystery is solved. This so much frightens Adso that he mutters to himself: «I was afraid my master would enter abruptly, seize my arm, and observe in the throbbing of my veins my secret, of which I would have been greatly ashamed» (Eco 1986: 209).

\section{The structure of the Citadel}

One of the most intricate parts of the story is the layout of the mysterious structure of the citadel, and especially its library. Brandon P. Newlon (2012) in his paper entitled, «Beasts and Buildings, Religious Symbolism and Medieval memory» has discussed the structure of the abbey and how it is related to religious symbolism. Umberto Eco himself has stated about the design and editing of this section before writing the story. «I conducted long architectural investigations, studying photographs and floor plans in the encyclopedia of architecture, to establish the arrangement of the abbey...» (Eco 1983: 25) At the beginning of the book, he seems to oblige himself to provide the reader with the abbey's map, which at the same time serves to make the story more believable. The astonishment of William and Adso of the extraordinary structure of the abbey is vivid in their conversation both before entering the monastery and at the end of the winding path to the monastery. In fact, the library has a unique structure. It is the tallest part of the complex, with its north side resting on the mountain slope and, as Adso puts it: 
This was an octagonal construction that from a distance seemed a tetragon (a perfect form, which expresses the sturdiness and impregnability of the City of God), whose southern sides stood on the plateau of the abbey, while the northern ones seemed to grow from the steep side of the mountain, a sheer drop, to which they were bound. I might say that from below, at certain points, the cliff seemed to extend, reaching up toward the heavens, ... (work of giants who had great familiarity with earth and sky) (Eco 1986:16).

He also notes that the shape and structure of the abbey as one approaches it on a stormy day is extremely frightening: «I can certainly see the sign of omens inscribed in the stone the day that the giants began their work...» (Eco 1986: 16).

It is therefore repeatedly emphasized that the building is the work of the giant, and it is also stipulated that in ancient times, it was built for an unknown purpose (according to William, Adso and other monks) and then later was used as an abbey. It is noteworthy that despite the exact description of the abbey's situation and the exact time of the events and even the exact time of the day, the location of the abbey remains enigmatic. Although Adso tries to keep in accordance with the narrative plot of the book, along with its inhabitants' will, and never discloses its exact location, the abbey itself is placeless. The point that justifies its placelessness is that even after the collapse and total destruction of the abbey, still there is no mention of its location. It can be said that the abbey's existence in this novel can be an interpretation of the divine cities in mythology and oriental texts resembling the paradise. However, while these cities are utopian, because of being inherently wicked and cruel they are turned into dystopia through the ironic language of Eco. Var-e Jamkard, first mentioned in the book of Avesta is one of the most famous celestial cities and it is possible that Eco has read about. The story is that King Jamshid, who had the full support of Ahuramazda, was commissioned to build a garden or a place to save the creatures from the approaching dire winter that would threaten the survival of every living thing. Then, Ahuramazda advised him to build the Var for keeping the best male and female seeds up there safe. (Avesta Fargard 2, paragraph 21)

The phrase «up there» implies that this place is not on the ground. Especially that this city is a sanctuary of stars, since the moon and sun are seen only once a year because a day in this city is equivalent to one year on earth. In the Shahnameh, the construction of the city is more explicitly attributed to the giants. In other words, according to the Shahnameh, the giants that build the city for Jamshid. (Ferdowsi 1997:(vol.1) 41).

Another famous celestial city found in the Shabnameb is the city that Siavash built on his own in his self-exile location in Turan. The city is called Siavashgard built on top of a mountain that reaches from the sky to the moon. It is an example of a paradise where there is no room for extreme heat or cold, disease and death. (Ferdowsi 1997: (vol.1) 106\&107) 
In addition to Shahnameh, in mythological texts and other literary texts, such as the Nizami's Haft Paykar, as well as folk tales and stories, there are traces of such cities, often belonging to the giants or the fairies. As in one of the stories of The Thousand Nights and One Night, there is a reference to a city like this, «...Hassan, saw a very tall building and asked Magi: 'Whose is this palace? Magi said that it belonged to demons... Then went on for seven days and they saw a cloud between the east and the west. Magi said that it was a high mountain piercing through the cloud and was so high that having the clouds beneath» (Tesouji 138 /2010: 187). This view of a mountain with a building in the middle of the cloud is consistent with Adso's view of the Citadel in the foggy weather that the observer does not know if the fog rises from the bottom of the valley or vice versa, covering the citadel, the building and then the whole valley.

\section{Philosophical Reflections}

Since Eco is a medievalist and the time and place setting of The Name of the Roses takes place in the medieval Gothic monasteries, many of the important and controversial issues that were present among scholars of that day are discussed in the book. Topics, such as the transcendent beauty as the ultimate attribute given to God, views on the ultimate destiny of man and his afterlife, and finally the reflection of the first impulses of modernity and religious tolerance, are embedded within the intricate plot of the novel. One of the most important topics Eco deals with is "laughter" as well as other topics such as the nature of love and beauty, sleep and dream and the like. It can be said that in all these, the traces of the wisdom of the Orientals are evident.

\subsection{Laughter}

In The Name of the Rose, there are several discussions about laughter, whether or not God or Christ is able to laugh leading to serious debates among different theologians, including William and Jorge. Diego Fasolini states, «Adapting, deconstructing, and even undermining Aristotle's Poetics in its epistemological integrity, and in general the Philosopher's theory of comedy, Umberto Eco develops his pseudo-theological dissertation, putting forth a rather peculiar doctrine concerning laughter, filled with cultural, and theological implications» (2006: 125).

William and Jorge are discussing in the library whose discussion reminds one of Avicenna's viewpoints that considers laughter and crying as human traits. Avicenna states, «When human being sees rare objects, he shows a kind of reaction called surprise, making him laugh; this is one of the properties of a human being» (Avicenna 1953:211). In this novel, William expresses something like Avicenna, "Monkeys do not laugh; laughter is proper to man, it is a sign of his rationality» (Avicenna 1953:79).

In addition, a more important debate found in the book is the dispute between Christian theologians over whether Christ laughs or not. (Eco 1983: 81) If one accepts that Christ is part of the divine 
spirit and, in some cases, the incarnation of God, then, the idea of Christ laughing reminds one of the idea proposed by Zakaria Razi (Rhazes) which considers pleasure and pain to underlie one's belief. Pleasure to him is a way of being free of pain. This is contrary to Aristotle's view that pleasure is an existential thing. Razi's ideas generated many theories, leading to much debate among Islamic philosophers and theologians. His views led many philosophers and Islamic scholars to believe in the divine essence of pleasure, and devotion. They, of course, refrain from using the word joy and laughter for God because they consider it part of human traits. Therefore, they use a special Islamic term (Bahjat) instead of happiness. After Razi, Avicenna in his book Al-Isharat attributes the essence of happiness (Bahjat) to God. However, most theologians of the time disagree with him, some, including Nasir Khusraw and other Ismaili adherents, have strongly criticized that viewpoint. ${ }^{1}$ Referring back to the issue of Christ's laughing, it is worth noting that the debate in this novel lacks the depth of similar debates among oriental philosophers and scholastic theologians, but the nature of the debate is undeniably the same.

\subsection{Sleeping and Dreaming}

In one part of the story, Adso sees a strange long dream and tells the dream to his master. His dream is a strange mix of real places and people with unusual and bizarre atmosphere and functions. However, from a semiotics perspective as well as from a dream psychology perspective, these landscapes are not unrelated to what goes on in Adso's state of mind, including his world as an adherent; they show how deeply he believed in medieval theology and Biblical stories. In his dream, Noah for instance enters with a shovel in hand, or Jonah puts a Pumpkin on the table, Jesus jokes with the apostles, and the praying book of Remigio (the cellarer who is condemned and burned) is like a scorpion. This is not unrelated to the two cases of murders in the monastery, both of whom have been poisoned. In other words, in Adso's dream, an upside-down world is represented, showing the real world and the nature of the global reality in which he lives. ${ }^{2}$ In the debate between Adso and William about sleep and dream, Adso's conception of the dream is in line with that of Avicenna who believes that there are certain types of dreams that do not need interpretation and that they occur when «the self (ego) suppresses the imagination. It will then be able to hold its understanding (vision) fixed so that it is actually present in the subconscious, and the viewer's dream holds it as it is in the memory» (Avicenna 1991: 181). For the dreams that need interpretation, Avicenna says: «If the self (ego) fails to hold its understanding as it is in the memory, then In such cases, few parts of the dream can be interpreted» (1991: 182). Avicenna

1 The basis of the theologians' argument is that pleasure is either Old (Qadim) or incidental (Hadith). If happiness is Old, it is incompatible with God being old because then it is considered two Olds (or two Gods) that it is some kind of heresy. If happiness is incidental, then it means that it happened in God and hence, God is the place of events. That is, something was once absent in God and later happened which is not compatible with the absolute perfection of God.

$2 \mathrm{By}$ the way, William also learns about the nature of comedy and, ultimately, the association of all these crimes with the missing comic book of Aristotle, hidden in the library. He finds that in Aristotle's view, the comedy turns the world upside down and dream-like to better understand its reality. 
goes on to elaborate on why all dreams cannot be assumed to be right and differentiates between different types of sleep. (1991: 185)

Avicenna's discussion on this issue is detailed and is beyond the scope of this article. But it is worth mentioning that in the book The Name of the Rose, Avicenna's argument, which regards sleep as a representation and reflection of the perceptions of life, is quoted by William. However, Adso agrees with that part of Avicenna's view that considers the dream as a divine message. (Eco 1986: 256)

\section{Direct references to individuals}

Umberto Eco has never referred to Oriental sources in any debates, lectures, and interviews. However, occasionally, in some pages of the novel, some Oriental scholars and sages are mentioned. For instance, Adso, while talking about his experience of making love with a girl in the church, describes himself as somebody who has gotten melancholy and lycanthropy. He then points to a text of Abu-Bakr Al-razi that argues about this kind of disease, as follows: «...my eyes fell on the lines attributed to Abu-Bakr Muhammad ibn-Zakariyya ar-Razi, who in a Liber continens identifies amorous melancholy with lycanthropy, which drives its victim to behave like a wolf...» (Eco 1986: 208) Furthemore, the other point directly stated is found in Adso's essay on love affair and his confessional writing. Here, he openly talks about Avicenna and other Oriental scholars and their methods of treating and curing the disease of love. In addition, Adso talks about an Arab, or The Old man of the mountain ${ }^{3}$ (Eco 1986: 105) which is a literal translation of the term «Sheikh al-Jabal», a common nickname of Hasan Sabah (d. 518 AH). Hassan Sabah was the head of the famous Ismaili sect whose supporters used to carry out political assassinations. He was known to offer his followers opium and hashish before being sent on secret missions. That is why, the historians called the sect the assassins. Sometimes instead of calling Hassan Sabah, Sheikh al-Jabal, they referred to him as Sheikh -al-Hashashin. (Daftary 1997: 273)

Also, William, talking about the ways of decoding mysterious handwritings, refers to the book of Alwashiyya an-Nabati, an Arab writer which says: «if you know a bit of the learning of the Arabs. The best treatises on cryptography are the work of infidel scholars, and at Oxford I was able to have some read to me... Abu Bakr Ahmad ben Ali ben Washiyya an-Nabati wrote centuries ago a Book of the Frenzied Desire of the Devout to Learn the iddles of Ancient Writings, and he expounded many rules for composing and deciphering mysterious alphabets, useful for magic practices but also for the correspondence between armies, or between a king and his envoys» (Eco 1986: 105).

3 Le vieux de la montagne in French. 
Finally, the point which seems to have affected the end of the story belongs to Jorge (page 236) that talks about the command given by one of the Muslim caliphs regarding burning books, referring to Umar al-Khattab, the second caliph of the Muslims (Caliph 13 -23 AH / 634 - 644 AD). Ibn Khaldoon in the Muquaddimah states that «when the Muslims conquered Persia and came upon an indescribably large number of books and scientific papers, Sa'd b. Abi Waqqas wrote to 'Umar b. al-Khattab, asking him for permission to take them and distribute them as booty among the Muslims. On that occasion, Umar wrote him: 'Throw them into the water. If what they contain is right guidance, God has given us better guidance. If it is error, God has protected us against it.' Thus, the (Muslims) threw them into the water or into the fire, and the sciences of the Persians were lost and did not reach us» (Ibn Khaldun 2005: (chapter 6 (18) 352).

\section{Conclusion}

The Name of the Rose, though a fictional work, shows the affinity of civilization, cultures and nations through intertextual use of many philosophies, folk tales, and legends religious and secular. The novel is a complex web of ideas and symbols signifying the intricate pattern of human existence. 


\section{Bibliografia}

Avesta. (1375/1996) Ed. Jalil Doustkhah, Tehran: Morwarid.

Avicenna (Abu Ali Sina) (1370/1991). The Canon of Medicine (Ghanoon dar'Teb). Trans. Abdolrahman Sharafkandi. Tehran: Soroush.

Avicenna (Abu Ali Sina) (1332/1953). Al-Isharat wa al-Tanbihat. Ed. by Ehsan Yarshater. Tehran: Anjoman Asar Melli.

Bondanella, Peter (2009) «Eco and the Tradition of Detective story», pp. 90-112. In Peter Bondanella (Ed.). New Essays on Umberto Eco, Cambridge: CUP.

Capozzi, Rocco (1989) «Palimpsests and Laughter: The Dialogical Pleasure of Unlimited Intertextuality in The Name of the Rose». Italica, Vol. 66, No. 4, pp. 412-428.

Coletti, Theresa (2009) «Eco’s Middle Ages and the historical novel», pp. 71-89. In Peter Bondanella (Ed.). New Essays on Umberto Eco, Cambridge: CUP.

Daftary, Farhad (1376/1997) The Assassian legends, Myths of the Ismailies. Trans. Fereydoon Badrei. Tehran: Farzan.

Eco, Umberto (1986) The Name of the Rose, Trans. William Weaver. NY: Warner Books.

Eco, Umberto (1984) Postcript to The Name of the Rose, Trans. William Weaver. San Diego, Newyork,London: A Helen and Kurt wolf Book.

Fasolini, Diego (2006) «The Intrusion of Laughter into the Abbey of Umberto Eco's 'The Name of the Rose': The Christian Paradox of Joy Mingling with Sorrow», Romance Notes, Vol. 46, No. 2, pp. 119-129.

Ferdowsi Tusi, Abul-Qâsem (1376/1997) Shahname, Ed. Saeed Hamidian, Tehran: Ghatre.

Gorgani (al-Jurjani), Isma'il ibn Husayn (1356/1977) Zakhireye Khwarąmshahi, Ed. by Jalal Mostafavi. Tehran: Anjoman Asar Melli.

Hafez, Sabry (1989) «The Name of the Rose: Time and Dialectics of Parallel Structures», Alif: Journal of Comparative Poetics, No., 9, pp. 36-48.

Haft, Adele J., White, Jane G., \& White, Robert J. (1999) The Key to the Name of the Rose. Ann Arbor: The University of Michigan Press.

Halabi, Aliasghar (1373/1994) Tarikh Falasafe dar Iran wa Jahan-e Eslami, Tehran: Asatir.

Ibn Khaldun,Abd -al Rahman Muhammed.(1967,2005) Trans: Franz Rosenthal.New Jercy: Princeton University Press

Khayyam, Omar (1391/2012) Rubáiyát, Tehran: Behzad.

Mardrus, J. C. (1964) The Book of The Thousand Nights And One Night, Vol.1, London: Routledge.

Mas'udi (Al-Mas'udi), 'Abū al-'asan 'Alī ibn al-'usayn (1388/2009), Muruj al-Dhahab wa Ma'adin al- 
Jawaher, Trans. by Abolaghasem Payande, Tehran: Elmi va Farhangi.

Monshi, Abomaali Nasrollah (1362/1983) Kelile va Demne, Ed. by Mojtaba Minovi, Tehran: Tehran University Press.

Nasir Khusraw, Abu Mo’in Hamid ad-Din (1341/1962) Zad-al Mosaferin, Ed. by Muhamad Bazl alRahman. Tehran: Kaviani.

Newlon, Brandon P. (2012) «Beasts and Buildings, Religious Symbolism and Medieval memory». http://citeseerx.ist.psu.edu/index.

Nizamīì Arūzì-I Samarqandī, Ahmad ibn Umar ibn Alī (1327/1948) Chahar Maghaleh (Four Discourses). Ed. Muhamad Moein. Tehran: Armaghan.

Nizami Ganjavi Mu’ammad Ilyās ibn-Yūsuf (1327/1948) Eskandarname, Ed. Pezhman Bakhtyari. Tehran: University Press.

On'or-al-Ma'āli, Kaykavus Qābus b. Vošmgir (1368/1989) Qābus-nāma, Edited by Gholamhosein Yousefi, Tehran: Elmi Farhangi.

Razi Abū Bakr Muhammad ibn Zakariyyā (1381/2002) Teb-e Roubani (teb-alnofous), Ed. Parviz Azkaei, Tehran: Ghalam.

Rumi, (2004) The Masnavi, Trans. Jawid Mojaddedi. Oxford: OUP.

Tabari, Abū Ja'far Muhammad ibn Jarīr (1368/1989) Tarikh-e Tabari (known as History of the Profits and Kings. Trans. by Abolghasem Payande, Tehran: Asatir.

Tesouji Tabrizi, Abd-al latif (1389/2010) The Thousand Nights And One Night (vol. 5) (Persian: Hezar wa Yek Shab), Tehran: Jami. 